もこれら各 Divisionごとに行われ，この内, Engineering Properties and Structure (EPS), Extrusion, Injection Molding が 3 大 Division であり, 連日 20 件以上の発表が あった（図 2)。今回，筆者は Flexible Packaging Division の Session で「Effect of Gas-Transmission Property in Modified Atmosphere Packaging for Fresh Produce」と いう題目で発表を行った。この Division と共に, 前述の EPS Division を中心に聴講した. 以下にそれらの Session における内容, 筆者の所感を述べる.

Flexible Packaging Division では, BP Chemical, Chevron, Dupont, Equistar,Nova と言ったポリオレフィン系レ ジンメーカーからフィルムの諸特性（ブロッキング, 衝撃 強度, ヒートシール性, ホットタック性等）を樹脂の構造 特性（短鎖分岐度分布, 結晶相の配向, 緩和時間, 表面粗 度等)に着目して解析した結果の報告があった。中でも BP Chemical より報告のあった LLDPE フィルムのブロッキ ングがヘキサン抽出量（低分子量成分）よりも短鎖分岐度 に依存することを AFM（Atomic Force Microscope）や TOF SIMS (Time of Fright Secondary Ion Mass Spectrometer）での表面解析結果より結論づけていた報告が目 新しいものであった.

また, Solcas Polymer, Kraton Polymers, Queen's University からは環境対応を意識した「PAN ホモポリマーに よる二軸延伸ハイバリアフィルム」「SB ブロックコポリ マーを使用した可塑化塩ビフィルム代替フィルム」,「ハイ バリア $\mathrm{EVOH}$ エマルジョンコート組成物」等の発表があっ た.この中で注目したのは, Solcas Polymerから報告の あったもので，PANに ethylene carbonateを 35〜 45\% 添加した可塑化キャストフィルムを二軸延伸した後, 可塑 剤を回収して製品化する発表であった。一見高コストにな りそうなプロセスであるが, 発表者は「クローズドシステ ムにすることにより他素材のハイバリアフィルムとの競争 力は充分ある」と強調していた。また, 食品に接触する用 途には使用可能かとの質問に対し,「可塑剂は最終製品で は $15 \mathrm{ppm}$ 未満にでき,この量ならばFDAの Approval は得られる」とのことであった。
EPS Division では Polymer Blend Session で Oklahoma University から Nylon 6 と LPE の相溶化剂として亜鉛 中和型アイオノマーを用いることにより LDPEの分散ド メインサイズを微小化することができ，機械特性が大きく 改善しうるとの発表, Polymer Property under Deformation Session で Dow と University of Rochester から報告 のあった二軸延伸 PS フィルムのインフレ時の内部応力と バブル破壊の関係を調べた発表等が目を引いた。昨年と同 様に構造解析のオンライン計測に関する発表も数多く行わ れており, 中でも University of Akronからのオンライン 複屈折計と X 線回折を利用し, 一軸延伸時の構造解析を PP P PLA 等について行った発表が目を引いた。オンラ イン計測により，延伸中と延伸後の緩和の影響を区別して 配向状態を議論できるようになったとのことであった。

一方, Nanocomposites Sessionでは連日発表会場は立 見が出るほど聴講者が多かったが, 内容としては目新しい ものはないように思われた。 ただし, 従来の Nylon 系か ら汎用のポリオレフィン系や生分解性樹脂として注目され ている PLA といった素材への展開が進められているよう に見受けられた。このため, マトリックス樹脂との相互作 用を高めるためナノクレーを表面改質したり，マトリック スに極性基を導入する等して Composites の特性を議論す る発表が目に付いた，以上，筆者が聴講した限られた範囲 の内容を述べさせていただいたが，最後に ANTEC 全体 を通しての所感を述べる. ANTEC は 20 以上もの Session が同時に進行する規模からも情報収集の場というよりも， 今後は積極的に情報発信の場として利用していくべきであ ると考える. Session での発表は 20 分のプレゼンテーショ ンと質疑応答の 10 分からなり, 質問は日本に比べると次 から次へという感じで発せられることが多い. 質問も自己 主張の一つと考えるアメリカ人の気質もあるかもしれない が, 発表内容を理解し, 自分のものにしょうとする積極的 な態度は筆者も含め多くの日本人は大いに見習うべき点で あると思う. 来年の ANTEC 2003 はテネシー州の首都ナッ シュビルで 5 月 4 日〜8 日の日程で開催される. 日本から の多数の参加者, 特に発表者を期待して本文の結びとしたい.

\title{
II. 破壊解析・射出成形セッションを中心に
}

山田浩 二*

筆者はこの度の SPE ANTEC 2002 に参加し, 講演発表 および聴講の機会を得た。今大会の概要は他の著者に譲る として, ここでは筆者が興味を持って聴講した発表につい ての感想を述べて, その参加報告としたい. なお, 筆者は 射出成形品のウェルドにおける破壊挙動に関する講演を 行った。したがって, 報告内容が破壊解析や射出成形など に限定されるものであることをご容赦願いたい．

\footnotetext{
* Yamada, Koji

大阪市立工業研究所プラスチック課

大阪市城東区森之宮 1-6-50（テ536-8553）

2002.5.22 受理
}

\section{1.プラスチック成形品の応力集中による破壊}

Heidweiller らは, 以前から小孔を空けた成形品の破壊 挙動を観察しているが, 亀裂の開始点が孔の形状に依存す ることを報告した. 鋭利な孔が開いている場合には亀裂は そこから発生したが, 図 1 に見られるようにスムースな円 形孔のある成形品の場合, 亀裂は孔からではなく成形品の 内部から発生して放射状に広がっていることがわかった。 これは成形品に加わる荷重の方向にも依存しているが，プ ラスチックの破壊挙動を研究する上で非常に重要な知見で ある。 


\section{2.電動機と油圧機との力率比較}

近年，中～小型の射出成形機の駆動機構は，油圧式のも のからいわゆる電動式が主流となっている。 その理由のひ とつとしてエネルギー効率がよい点が挙げられる. Dawson らは型締力 100 トンクラスの電動式射出成形機と油圧 機について, 力率 (power factor：見かけの電力に対する, 実際に仕事に用いられた電力の割合）を詳細に測定した。 この結果，同じモデル製品を同じだけ生産した場合，力率 は油圧機の 0.489 に対して電動機は 0.985 となり, 電動機 がエネルギー消費量に関して優位であることを数值をもっ て明らかにした。

\section{3．射出ウェルディング法}

2 つの部品を熱や高周波で溶着し，製品とする手法は広 く行われているが, Oliveira らは $2 つ の$ 部品の間にバイン ダーとなる樹脂を射出することで一体化させる方法を提案 した．回転プラテンを有する多色成形機（Ferromatic Mi-

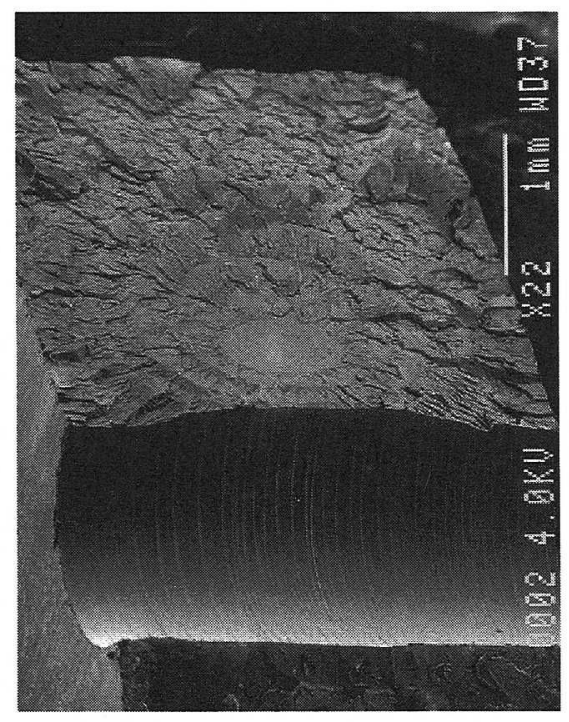

図 1 スムースな円孔を有する PMMA 成形品の引張荷重 による破壊面

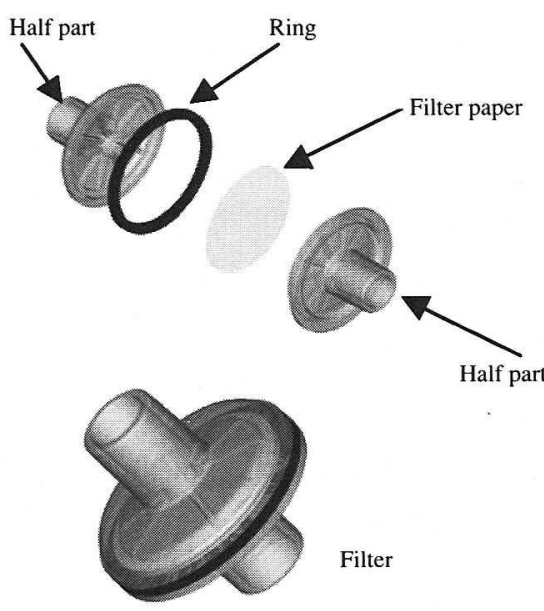

园 2 射出ウェルディング法によるフィルタ成形品（Ring （PP）を射出成形して各部品を溶着） lacron 製 K 85) を利用して, 図 2 に示したフィルターを挟 み込んだPP成形品をワンステップで製造する例が紹介さ れていた。バインダーとなる樹脂のメルト温度と融着強度 との関係について具体的に検討しており，また成形条件と 射出部品のモルホロジーとの関連性についても論じていた。

\section{4 。射出した樹脂の配向におよぼす保圧の影響}

射出成形においては, 通常ひけ防止のため保圧工程が必 須である. Pontesらは, 保圧によって成形品内部の樹脂 の配向がどのように変わるかを, 複屈折計で調べた. 特に 新しい理論を展開しているわけではないが，成形品を 15 から $30 \mu \mathrm{m}$ に薄片化して観察することで，スキン・コア層 の配向差, 保圧の影響による配向の変化などがわかりやす く説明されていた。 その一例としてPCを用いた成形品(肉 厚 $2 \mathrm{~mm}$ ）の断面を図 3 に示す. 複屈折によって生じた縞 模様の間隔が狭いほど配向度は大きい。この手法によって スキン層の配向が著しいこと, 保圧が高いほどコア層の配 向度が大きくなることが実際に観察された。ウェルド部に おける樹脂の配向緩和挙動と物性との関係を検討している 筆者にとって，その具体的な手法は非常に参考になった。

\section{5。発泡射出成形におけるウェルドラインの物性}

近年，無数の極微小な空孔を内部に有する成形品の研究 がさかんに行われている. Turng らはポリカーボネート の発泡射出成形により, ウェルドを有するダンベル試験片 を作製し, その物性を検討した. 実験手法としては Taguchi 法によるマトリックス処理で, 成形条件の最適化を行う一 般的な方法であるが, 成形条件が空孔の大きさや分布を支 配するため, ウェルドの物性と直接結びっけるのは難しい のではないかと感じた. 発表者に直接伺ったところ, 確か に解釈が難しいのは否めないということである.また,内部 の気泡がクッションの役割を果たすため, ウェルドライン
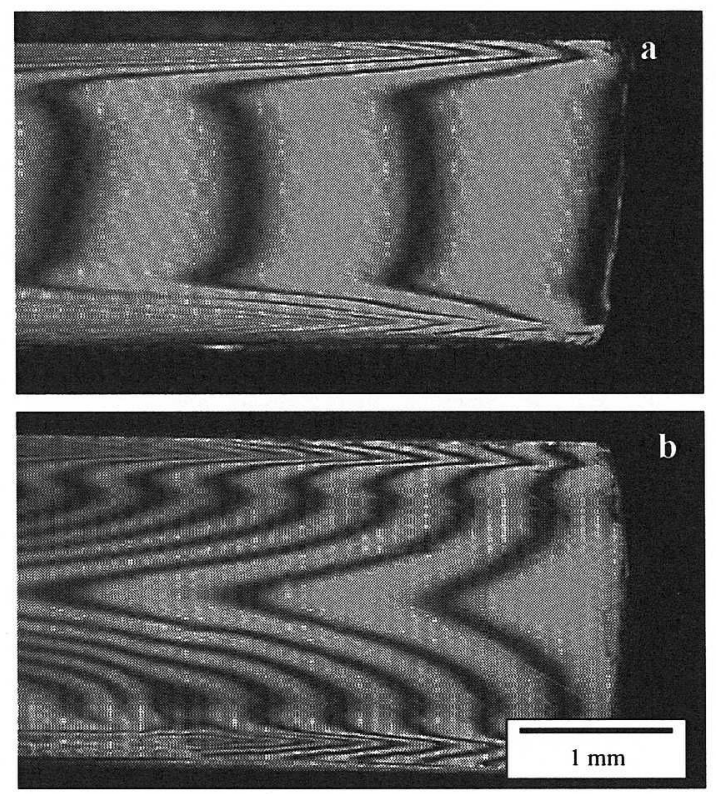

Flow direction

図 3 PC 射出成形品の複屈折画像 (a) 保圧 $12 \mathrm{MPa}$, (b) 保圧 $110 \mathrm{MPa}$ 
界面に保圧を十分に加えられないという問題があるようだ。 ウェルドラインの物性に関する講演としては，これ以外 にも落錘衝撃試験を行ったVianaらの研究や，吸湿によ るガラス繊維強化ナイロンの物性低下を論じた Belzらの 研究を聴講したが，ウエルド部を“物性が一様な面”とし てしか捉えられておらず，より詳細な検討が必要であると 強く感じた。

\section{6。振動射出成形によるウェルド物性向上}

Coulter らは射出スクリュを前後に振動させることで, 樹脂の配向緩和を狙った研究を行っている．しかし単に振 動を与えるだけでは，ウェルド物性が思ったほど向上しな かった過去の結果を受け，一つの改良法を提示した。図 4 のように振動にあわせてウェルド部の金型が動くようにし てウェルド部の樹脂を積極的に運動させようというもので ある．実用性は未知数だが，曲げ強度にはその効果が現れ た。通常の振動射出成形に比べて若干強度が増加すること, またスクリュ振動の周波数が小さいほど強度が向上するこ となどの結果を得た。

\section{7. 多色ラミネート成形 \\ (Multi-Component Laminate Moulding : MLM)}

型内に樹脂を射出後，2つのピストンを用いて樹脂を強 制的に流動させる方法は SCORIM 法として知られている。

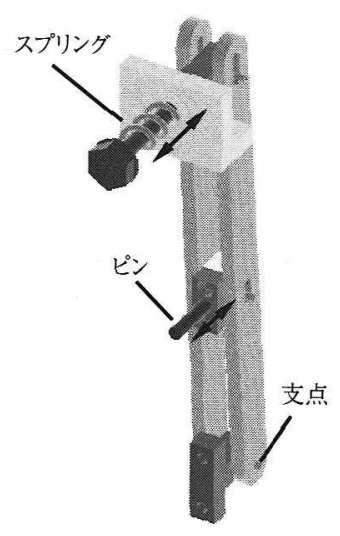

(a) アキュムレータ

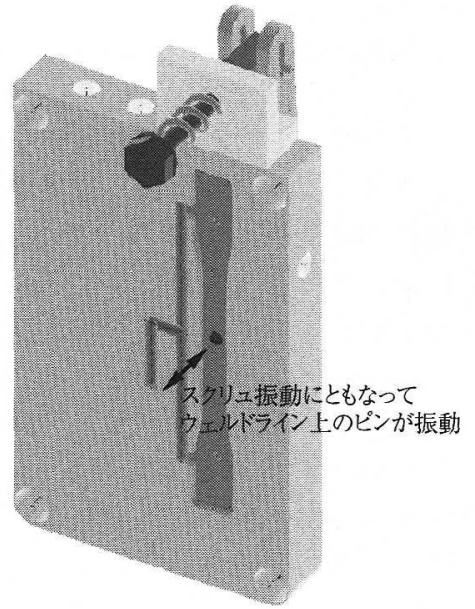

(b) アキュムレータを金型に 装着したところ
図 4 振動射出成形におけるウェルド部アキュムレータ

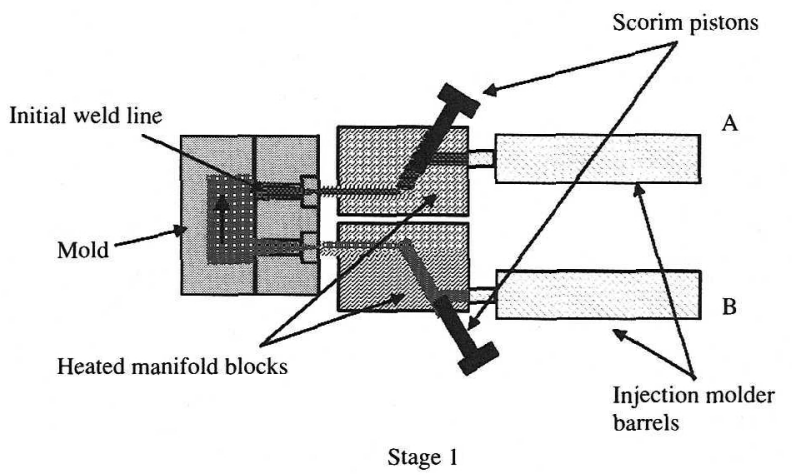

図 5 多色ラミネート成形（MLM）の概念図
この SCORIM 法を提唱した Allan,Bevisらは，多色成形 法と組み合わせることで厚さ方向に複層構造を形成させる 方法を提案した。装置の概略図（図 5）によって理解でき るように，型内にいったん A を充填後，Bを射出してサ ンドイッチ構造とする。次に $\mathrm{A}$ 側のピストンを押して, コア材 $\mathrm{B}$ 層の内部に A 層を形成させる。次にB 側のピス トンでさらにその内側に B 層を形成させる。この工程を 繰返すことにより，複層構造が形成されるというものであ る.実際に得られたものとして図 6(a)に示すように 4 層 構造の成形品が，また金型を電磁誘導加熱する BSM (Bright Surface Molding, 旭化成) と組み合わせること により，図6(b)に示す 6 層構造の成形品を報告していた. 本方法では SCORIM 法と同様に成形品物性の向上が期待 されるが, 衝撃強さに著しい効果があることがわかった。

\section{8. 射出発泡成形のための新規なノズル構造}

従来 $\mathrm{CO}_{2}$ や $\mathrm{N}_{2}$ を用いる射出発泡成形では，混練性を高 めた特殊なスクリュ形状やガス注入用のポートをバレルに 設けるなど大掛かりな改造が必要であった。ドイッ IKV の Habibi-Sasan らはガスをより簡便に材料に加える方法 を提案した。既存の射出成形機を使用し，ガス注入機構を 備えたノズルを用いる手法である，アイディアとしては当 然考えられる方法であり，ベースとなる技術はすでに保有 していたとはいえ，それを具体化し実行するところが IKV
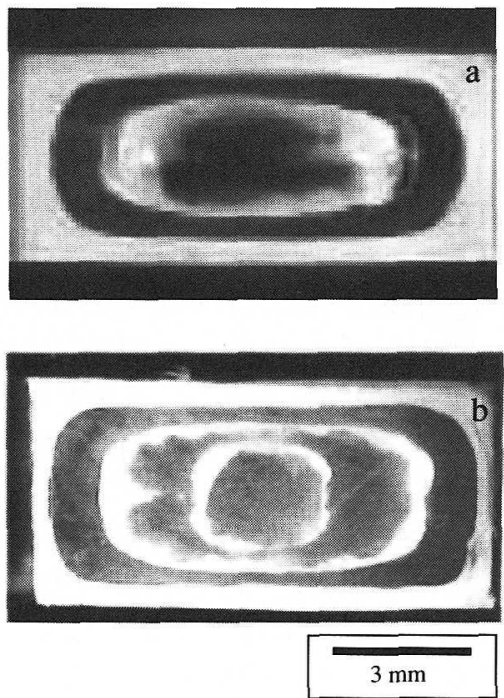

図 6 MLM による成形品断面図

(a) 4 層構造, (b)BSM を併用した 6 層構造

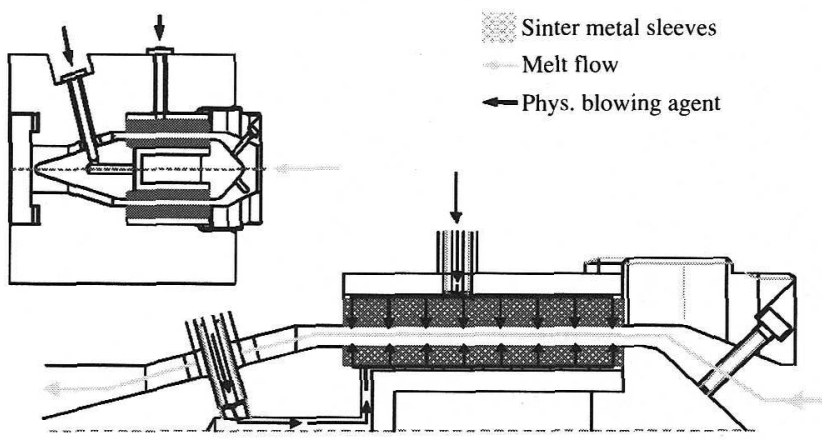

図 7 射出発泡成形用新規ノズル 
の技術力の優れた点であろう（IKVはこのプロトタイプ を 2000 年に発表している). 図 7 に示すようにノズル内の 樹脂流路を肉の薄い円筒状とし，その流路を多孔質の焼結 金属で作製して，高圧でガスを注入する．成形品へのガス 注入量の目安となる密度低下率が報告されていたが，それ によると $\mathrm{PC} / \mathrm{ABS}$ の場合，肉厚 $2 \mathrm{~mm}$ で $10 \%$ 程度，肉厚 $8 \mathrm{~mm}$ では $60 \%$ の密度低下が示された。なお，PS や TPE など他の材料を用いてもほぼ同じ值を示しており，材料に はあまり依存しないようであった。

以上, 非常に雑駁ではあるが, 筆者の興味のままに述べ
させていただいた，全体を概観すると企業の技術や製品の $\mathrm{PR}$ の域を出ないものもあったが，個人的には筆者と同様 の研究を行っている研究者との意見交換や, 今後の実験に おいてヒントとなる技術など, 有用な成果が得られたと満 足している. 今回の ANTECでは 1000 を超える発表があ り,また, 著名な観光地で日本人にもゆかりの深いサンフラ ンシスコで開催された。その割には日本からの参加者は意 外に少なかったように感じた. 経費や滞在日数を考慮する と気軽に参加するわけにはいかないが，もっと積極的に日 本からの発表や情報発信がなされるべきではないだろうか.

\section{III. 自動車・製品設計を中心として}

私は今回初めて ANTEC に参加し, Automotive Division の Automotive Application Analysis の Session にて「A New Approach of Parts Design for FMVSS 201 U Using Simple Deformation Method and CAO Technique」と題 した研究発表を行う機会を得た。私は同 Sessionの発表と, Automotive と Product Design and Development $の$ Divisionの発表および CAE に関する発表を中心に聴講した. 今回, Automotive Division では Automotive Application Analysis と Automotive Advances in Materials の 2 つの Session が設けられていた.

Automotive Application Analysisの Session では 2001 SPE Automotive Award で取り上げられた最新のプラス チック部品についての報告, 長繊維補強熱可塑性樹脂のイ ンラインのコンパウンディングに関する報告, 燃料系部品 のバリア材における燃料の拡散係数や浸透性の評価方法に ついての報告，車体シール解析における TPE 試験データ に関する報告等が発表された.この中で, 燃料系部品の浸 透性に対しては 2 件の発表があり，環境問題面における， 米国での燃料蒸散に関する新しい規制に対応する報告とし て注目される。

Automotive Advances in Materials の Session ではブ ロー成形スポイラー用の耐熱・耐衝撃 ABSに関する報告, 空気・燃料の統合システム用のエンジニアリングプラス チックに関する報告, 導電性樹脂と非導電性樹脂との付着 強度における導電性粒子の影響に関する報告, エアーバッ ク用 TPVに関する報告, 共押出成形されるウェザーシー ル用 TPVに関する報告, 燃料系部品用のエステルーエー テルブロックコポリマーに関する報告等が発表された.

Product Design and Development Division では, Designer and Product Development Job Search Forum の Session, Materials and Design Effects and Selection の Session, Design/Simulation and Product Development Planning の計 3 つの Session が設けられ，さらに，Blow Molding Division とのジョイントの Session として Con-

\footnotetext{
* Hirota, Tomoo

住友化学工業侏) 樹脂開発センター

袖ヶ浦市北袖 2-1（宁299-0295）

2002. 6.5 受理
}

cepts and Cooperation for Blow Molding and Design $の$ Sessionが, Decorating and Assemblyの Division との ジョイント Session で Design Factors Including Safety, Decorating, and Recycling の Session が設けられた.

その他興味深かったSession としては, Extrusion Division Die Design and Modeling $の$ Session, Injection Molding Division の CAD/Simulation 1〜3の各 Session で あった．私の興味があった発表の時間が重なることが多く， 全てを聴講できたわけではないが，興味深かった報告につ いて以下に述べる。

Materials and Design Effects and Selection $の$ Session では，バイエル社の Olaf J. Zoelllner 氏らが，樹脂/金属 ハイブリッドの射出成形技術を用いた強度を要求される部 品に対して，コスト面，重量面，機能面等にすぐれた構造 体の例を報告している。 また, Ticona 社の Paul Wyluda 氏は，アセタールコポリマー製の歯車の準静的な負荷状態 の挙動について実験と FEM の結果の比較を報告している。

Concepts and Cooperation for Blow Molding and Design の Session では, カナダ国立研究所の D. Laroche 氏 らが複雑形状パリソンの変形挙動のソリッド要素および シェル要素を用いた FEM の結果と実験結果を比較し, 板 厚の予測精度の面におけるソリッド解析の有用性を報告し ている. また, 同研究所の F. Thibault 氏らは, カーペッ 卜添合のブロー成形部品の板厚分布とそり量を目的関数と し，ダイギャップとカーペット側の熱伝達係数を設計変数 にした最適化例を報告している.

Die Design and Modeling の Session では 8 つの発表の うち 5 つが FEM を用いたもので, 現在, ダイス設計にお いても FEMを用いた仮想試作が注目されていることを感 じたささらに，本 Session ではダイス設計への CAO 技術 適用に関する発表が 3 件報告されており，そのいずれもの が, ダイス出口で均一流動となるようなダイス寸法の最適 設計に関する発表であった。

CAD/Simulation 1 と 2 の Session では, 清華大学の Rong - Yeu Chang 氏らが三次元充填解析のメッシュ生成 方法として非構造四面体メッシュと三角柱メッシュを組み 合わせることで, 複雑形状対応への柔軟性と計算の安定性 を両立したメッシュ作製法，および有限体積法とVOF 法 